\title{
INSTITUTIONAL LOGIC AND THE TRANSFORMATION IN THE BANKING SECTOR: FROM TRADITIONAL LOGIC TO FINTECH
}

\author{
Alana Bauer Lacerda, Felipe Robaski and Fernando Dias Lopes \\ Universidade Federal do Rio Grande do Sul, Brazil
}

\begin{abstract}
Banking institutions are faced with profound changes coming from the development of technology and the consequent entry of a new player in the field: fintech companies, startups focused on financial services, with strong adherence to the digitally native public, as well as those underserved by traditional banks. From the approach of institutional logic, and the combination of document analysis and in-depth interviews, we contribute with the knowledge of how banks are being able to combine the previously dominant traditional logic and fintech logic into a hybrid model. The analysis shows how traditional banks absorb fintech practices and how the introduction of fintechs in the field promotes changes not only in the banking sector, but also in other spheres. The interaction of the logics that shape this change emphasizes a unidirectional dynamic, in which only the logic of fintechs influencing the traditional banking logic was observed.
\end{abstract}

\section{KEYWORDS}

Bank, Banking Sector, Fintech, Institutional Change, Institutional Logics

\section{INTRODUCTION}

The banking sector has undergone profound changes in recent years. From technological developments in the last decade and changes in consumer behavior, such as the intensive use of mobile, new opportunities have been created in customer service, which increasingly seek convenience and lower cost in services. Banks seek to keep up with the benefits that new technologies provide and have always been major investors in the area, lagging behind governments only worldwide (Febraban, 2019).

The new technology scenario has enabled the growth of a new entrant in the financial system that is challenging traditional models of banking services - the so-called fintech companies. These startups that work in the financial sector have a strong adherence to the public that seeks the convenience of digital and mobile channels to the detriment of the physical and sometimes lengthy care of a traditional bank (Financial Stability Board, 2017).

Given this, we seek to analyze the transformations of the banking sector and what would be the role of the fintech companies in this new configuration. From the question: "How do institutional logics manifest themselves in the banking sector from the introduction of fintech companies in this context?", this research seeks to explore the new characteristics of the banking sector, as well as the values, beliefs, strategies, and mechanisms involved in a possible new institutional logic.

\section{BANKING SECTOR SETOR - DATA AND RECENT CHANGES}

Banks have always been major investors in technology, leading sectors traditionally associated with this area, such as telecommunications. In the Brazilian case, in 2018, for the first time in history, the total amount invested by banks was equal to public investment - a leader in technology investment - reaching R \$ 19.6 billion (Febraban, 2019). As information is both input and output of banks, this investment is justified by the increased internal complexity in system processing and also by the opportunities and advantages perceived through new products offered by technology providers (Correa, Fonseca, \& Meirelles, 2010). 
Nevertheless, the need for a high initial investment in communication, software and call center infrastructures, which until then was a barrier to new entrants and also favored banking concentration, has been drastically falling thanks to new technologies (Diniz, Fonseca, Meirelles, \& Roxo, 2011). In this context, fintech companies, technology companies that offer financial products from an innovative approach, are gaining notoriety, forcing the financial sector to rethink its business models (Miklos, HV, \& Lee, 2016).

The rapid growth of these new entrants is justified by a confluence of factors. First, the change in consumer profile - millennials and digital natives, who are looking for fast, convenient, low-cost financial solutions. Second, new Technologies and methods, which were already being followed and, in some cases, adopted by big banks such as Big Data, Blockchain, Design Thinking, and the intensive use of mobile, promoted innovations in the way financial services are provided. Moreover, the lack of interest of large banks in the provision of financial services in some areas, especially after the financial crisis, with higher capital requirements, opened the market for non-traditional and non-financial institutions to provide services. The combination of these factors has become an opportunity for new scalable business models, at a lower-cost than traditional banks, with their IT legacies in some cases inefficient (Financial Stability Board, 2017).

In Brazil, according to the Central Bank [BACEN] (2018), the sector's regulator, there are still few active fintech companies in the country. However, there is expected to be a significant increase, given the recent claims that the Institution has received and also the interest of investors and clients, considering the less expensive initial investment and also the ability to meet customer needs from new technology solutions. Recently, through Bacen Resolutions No. 4,656 and 4,657 April 2018, fintech companies' operations in Brazil were regulated, specifically in the area of credit through Direct Credit Societies (SCD), in which funding takes place through its own resources, or even through Peer-to-Peer Lending Societies (SEP), in which fintech companies perform the role of financial intermediary.

\section{INSTITUTIONAL LOGICS}

In their seminal essay on institutional logics, Friedland and Alford (1991) emphasize that the main institutional orders of Western society have a central logic that constitutes their organizational principles. These institutional orders are the market, the bureaucratic state, the family, democracy, and religion (or science). Its logic is based on a set of material practices and symbolic constructions. According to the authors, individuals can manipulate or reinterpret symbols and practices. In this context, the institutional transformations will occur from the creation of new social relations and new symbolic orders. Subsequently, Thornton and Ocasio (1999, p. 804) will define institutional logics as " the socially constructed, historical pattern of material practices, assumptions, values, beliefs, and rules by which individuals produce and reproduce their material subsistence, organize time and space, and provide meaning to their social reality".

Thornton and Ocasio (2008) systematize institutional logics into five principles that provide a greater understanding of the theory. Embedded agency: an assumption that contrasts with the rational choice approach. The authors cite Friedland and Alford (1991), according to which this principle presupposes the partial autonomy of individuals, organizations and institutions; Society as an Interinstitutional System: it is assumed that different sectors and social institutions have different logics. This view makes room for research on heterogeneity and agency, because the difference between logics will allow this observation; Material and Cultural Foundations of Institutions: the authors cite another argument by Friedland and Alford (1991) that each of the institutional orders in society has material and cultural characteristics, and the interaction between these forces explains development and change in the institutions; Multilevel Institutions: the authors argue that institutional logic, as a meta-theory, has become remarkably comprehensive, allowing to observe institutional logic at multiple levels, such as organizations, professions, markets and industries; and Historical Contingency: they argue that the influence of the great institutions of Western society will change over time, shifting their importance and combining in different ways.

Research on institutional logics will vary in describing the processes of change in institutions. The research by Thornton and Ocasio (1999) and Reay and Hinings (2005) propose a dominant logic that overlaps an old logic. Dunn and Jones (2010) advocate the coexistence of multiple logics in the organizational field in scenarios that operate with various institutional spheres and cite the research by D'Aunno, Sutton and Price (1991), in which the possibility of competing logics present is possible. in the same context. In such cases, organizations respond to external pressures by adopting some practices, within their limitations, but visible enough to ensure 
a minimum level of organizational legitimacy (D'Aunno, Sutton \& Price, 1991). Finally, the combination of conflicting logics results in the creation of hybrid logics, as described by Thornton, Jones, and Kury (2005) in their research.

The institutional logic was chosen as a background for this research because of the possibility of analyzing the dynamics of change in the field and how the introduction of a new logic produces its effects on the dominant logic.

\section{METHOD}

This is an exploratory research of qualitative nature. From this study, it is not intended to provide evidence that exhausts the research problem: on the contrary, our intention is precisely to explore aspects of the research topic, find new questions and a basis for future studies. We adopt an interpretative approach to analyze qualitative data from (a) document analysis and (b) in-depth interviews.

The documentary analysis is based on data from 16 editions of CIAB Febraban (Brazilian Federation of Banks) magazine, from 2017 to 2019. The interviews were conducted using a semi-structured questionnaire with five representatives from two banking institutions and one fintech company located in Porto Alegre, Rio Grande do Sul, Brazil. Representing bank 1, the superintendent and a manager linked to the digital transformation of this institution were interviewed; representing bank 2, two product management representatives were interviewed. Representing fintech, the CEO was interviewed. A total of two hours and twenty-seven minutes of interviews was done.

The documents and transcripts were analyzed by creating categories to identify the patterns and characteristics in banking business models and the combinations of institutional logics.

\section{RESULTS AND DISCUSSION}

Fintech companies gained strength from the 2008 financial crisis, also driven by the advancement of new technologies (especially mobile) and the changing consumer profile (Millenials). Documentary research shows that these companies, often with a single financial product, can expand their customer portfolios exponentially by one or two years. This expansion is explained by the fact that this type of company is based on (1) data analysis, more clearly identifying market needs, (2) proximity to the natively digital audience, and (3) breaching the trust pattern previously practiced between a financial institution and a client, and may absorb underserved clients in the financial market and those without access to banks, users who were often previously unable even to open an account.

These characteristics led banks to revise their practices and structure, moving ever closer to the "fintech model." The excerpt from the documentary analysis highlights the growing interest of traditional institutions in this new actor. "The attitude of the new consumer, who wants more agile services, innovative solutions and lower costs, has caused Brazilian financial institutions, in general, to change their posture and look at the fintech companies [...]"(CIAB FEBRABAN - $67 \mathrm{Jan} / \mathrm{Feb} 2017)$.

Document analysis also shows a relatively rapid onset of institutional logic change in the environment of large banking corporations. Issues such as the regulation of the sector came into discussion, as well as a significant increase in safety from new technologies, to allow the aggregation of elements of fintech logic in their practices. One of these elements is precisely the best use of data analysis, coming mainly from more significant interaction with customers, service from previously unexplored channels, and the insertion of the bank in a more social environment.

Regulation is a barrier to be overcome by traditional banks: "the central bank regulates banks a lot. So the bank is responsible for capturing the customers and assure their authenticity. So all this part of you getting new customers without a face to face approach, it generates a lot of bank needs and changes" (Interview 1). This regulation, which constitutes an obstacle to the traditional banking sector, is an advantage for fintech companies, which are still in the early stages of standardization. That said, banks are seeking greater flexibility with regulators to offer fully digital products without the need for physical controls (contracts) using other verifications such as biometrics. 
Agile methods are cited as a tool employed by teams in search of more creative products and services and solutions that explore different points of view of a problem. This new methodology contrasts with the traditional method used by large institutions, also known as the "waterfall method," whereby development occurred linearly, without much interaction between the working groups involved.

These methods are increasingly present in traditional institutions: "We realized that with the adoption of agile methods, everyone has room to talk and to give an idea, which generates much more wealth for product development" (Interview 2). The adoption of new methodologies varies among institutions according to their willingness to change their structure to fit the new logic. Thus, there are large institutions with a structure that is entirely separate from the corporate picture, which mimics the "startup culture," with multitasking teams, horizontal structures and is not influenced by traditional culture. Already other institutions try to adapt their existing staff, allocating employees of different groups in new formats to meet the new logic imposed. There are also cases of acquisition of startups or strategic partnerships.

The change in banking logic also mimics fintech companies concerning leaner structures: "By the end of 2017, there were 21,800 branches nationwide, according to Central Bank data. It's a reduction from 23,400 in the previous year, due to the readjustment and redefinition of the agencies, which are now divided between traditional agencies and those dedicated to service and consulting, a model more suited to the exponential growth of digital channels"(CIAB Febraban No. 74 - Mar/Apr 2018).

The table below compares the perspectives of what we call "traditional banking logic" and "fintech logic." It brings together the characteristics of a new "hybrid logic" that demonstrates changes in the banking sector.

Table 1. Traditional Banking Logic vs. Fintech Logic

\begin{tabular}{|c|c|c|c|}
\hline Characteristic & Traditional Banks & Fintech & Hybrid logic \\
\hline \multicolumn{4}{|l|}{ Product } \\
\hline \multirow[t]{2}{*}{ Characteristics } & Multiple Bank Predominance & Single Product Predominance & Multiple Bank Predominance \\
\hline & Large product portfolio & $\begin{array}{l}\text { Highest Specification / } \\
\text { Specialization }\end{array}$ & Portfolio specialization \\
\hline \multirow{5}{*}{$\begin{array}{l}\text { Development of new } \\
\text { products } \\
\text { Customization }\end{array}$} & Traditional project & Agile Methods & Agile Methods \\
\hline & management & Minimum Viable Product & Startup culture \\
\hline & Low customization & Alta customização & Increased Customization \\
\hline & Massification & High customization & Improved focus on \\
\hline & & $\begin{array}{l}\text { Focus on customer } \\
\text { experience }\end{array}$ & customer experience \\
\hline \multicolumn{4}{|l|}{ Operation } \\
\hline \multirow[t]{2}{*}{ Routines and Processes } & Some automation & High process automation & Some automation \\
\hline & Obsolete IT Legacies & High scalability & Increased Scalability \\
\hline \multirow{3}{*}{$\begin{array}{l}\text { Quality control and } \\
\text { improvement }\end{array}$} & Incremental changes & High customer interaction & Development of \\
\hline & Legal demands & Constant improvements & customer interaction \\
\hline & & $\begin{array}{l}\text { Development from } \\
\text { customer feedback }\end{array}$ & $\begin{array}{l}\text { Changes from customer } \\
\text { feedback }\end{array}$ \\
\hline \multirow[t]{3}{*}{ Regulation } & High regulation & Incipient Regulation & High regulation \\
\hline & Compliance & Low or no regulation & Compliance \\
\hline & Taxation & Low taxation & Taxation \\
\hline \multicolumn{4}{|l|}{ Management } \\
\hline \multirow[t]{3}{*}{ Decision Process } & Corporate governance & Quick decision process & Corporate Governance \\
\hline & Collegiate Decision & Centralized decision & Collegiate Decision \\
\hline & Processes & making & Processes \\
\hline Hierarchy & $\begin{array}{l}\text { Complex organization } \\
\text { chart, high specialization }\end{array}$ & $\begin{array}{l}\text { Lean structures, } \\
\text { multitasking professionals }\end{array}$ & $\begin{array}{l}\text { Experimentation of new } \\
\text { structures }\end{array}$ \\
\hline \multicolumn{4}{|l|}{ Marketing and Sales } \\
\hline \multirow[t]{3}{*}{ Clients } & Atomized & Public that has adherence to & Increased segmentation \\
\hline & Segmentation by income & new technologies & Flexibility targeting digital \\
\hline & range & $\begin{array}{l}\text { Underserved bank clients or } \\
\text { with no access }\end{array}$ & natives \\
\hline \multirow[t]{2}{*}{ Brand and Perceived value } & Tradition & Accessibility & Tradition \\
\hline & Reliability & $\begin{array}{l}\text { Experience } \\
\text { Lowest cost }\end{array}$ & Modernization \\
\hline \multirow[t]{2}{*}{ Relationship with clients } & Physical Agencies & Service predominantly & New online service \\
\hline & $\begin{array}{l}\text { Internet banking } \\
\text { Mobile }\end{array}$ & digital, internet or mobile & $\begin{array}{l}\text { channels, reduction of } \\
\text { physical branches }\end{array}$ \\
\hline
\end{tabular}

Source: authors 


\section{CONCLUSION}

The study of the banking sector as an institutional field allowed us to observe the interaction of logics that act in the transformation of what we call the "traditional logic" of big banks. First of all, it should be noted that the development of technology in the last decades has enabled increased security in electronic transactions, one of the foundations for both fintech companies and the banking industry to innovate and adopt new procedures.

Fintech practices are added to the traditional logic, showing the formation of a new hybrid logic, in which it is still possible to observe a traditional banking core adding characteristics from the logic introduced in the field. It is important to emphasize the unidirectionality of this interaction: fintech companies influenced banks, but we couldn't observe that the interaction with banks acted on the fintech logic. The introduction of this new logic in the field promoted the valorization of a model with high personalization, which responds more efficiently to the demands and thoughts of society, through more significant interaction.

Although traditional institutions do not lose space to fintech companies (banks continue to show exponential growth), the emergence of this new actor challenges them to review their structures and working methods, seeking to legitimize themselves in a market of constant technological transformations. This research also allowed us to observe that the changes are happening not only at the level of the banking organization but in the field, forcing the promotion of changes in the legal framework for the regulation of financial activities, for example.

From a theoretical point of view, this research offers an alternative view of the traditional and hitherto dominant banking model. This view was built on the exploration of theories and practical innovations present in the documentary analysis and reported in the interviews. As a result, we have a hybrid model created by combining conflicting institutional logics, comparable to other models.

As limitations of the research, we cite the need to expand the database from interviews, with the inclusion of new institutions that make up a more significant portion of the regional banking sector. These limitations provide a path for future research: in addition to expanding the database, analyzing the profile of institutions and professionals can help in a more detailed view of the phenomenon.

\section{REFERENCES}

Banco Central do Brasil (2018). Relatório de Economia Bancária 2018. Brasília. Retrieved August 02, 1019, from https://www.bcb.gov.br/content/publicacoes/relatorioeconomiabancaria/reb_2018.pdf.

Czarniawska, B. (2008). How to misuse institutions and get away with it: Some reflections on institutional theory(ies). In R. C. Greenwood, C. Oliver, K. Sahlin, \& R. Suddaby (Eds.), The Sage handbook of organizational institutionalism (pp. 769-782). London: SAGE Publications.

D'Aunno, T., Sutton, R., \& Price, R. (1991). Isomorphism and External Support in Conflicting Institutional Environments: A Study of Drug Abuse Treatment Units. The Academy of Management Journal, 34(3), 636-661. Retrieved from http://www.jstor.org/stable/256409.

Diniz, E. H., Fonseca, C. E. C., Correa, C. E., Meirelles, F. (2011). Visão de Futuro da Tecnologia Bancária. FGV: São Paulo. Retrieved August 03, 2019, from: https://pesquisaeaesp.fgv.br/sites/gvpesquisa.fgv.br/files/arquivos/meirelles_-_visao_de_futuro_da_tecnologia_bancaria_.pdf.

Dunn, M., \& Jones, C. (2010). Institutional Logics and Institutional Pluralism: The Contestation of Care and Science Logics in Medical Education, 1967-2005. Administrative Science Quarterly,55(1), 114-149. Retrieved from http://www.jstor.org/stable/27856090

FEBRABAN (2019). Pesquisa FEBRABAN de Tecnologia Bancária 2019. São Paulo. Retrieved August 03, 2019, from https://cmsportal.febraban.org.br/Arquivos/documentos/PDF/Pesquisa-FEBRABAN-Tecnologia-Bancaria-2019.pdf

Financial Stability Board (2017). Financial Stability Implications from FinTech: Supervisory and Regulatory Issues that Merit Authorities' Attention. Retrieved August 03, 2019, from https://www.fsb.org/wp-content/uploads/R270617.pdf.

Fonseca, C. E. C., Correa, C., \& Meirelles, F. (2010). Tecnologia bancária no Brasil: uma história de conquistas, uma visão de futuro. FGV ERA. Coord.: Sonia Penteado. São Paulo.

Friedland, Roger and Alford, R. Robert. 1991. 'Bringing society back in: Symbols, practices, and institutional contradictions,' in The New Institutionalism in Organizational Analysis, ed. Walter W. Powell and Paul J. DiMaggio, pp. 232-263. Chicago, IL: University of Chicago Press.

Meyer, R. E., \& Hammerschmid, G. (2006). Changing Institutional Logics and Executive Identities: A Managerial Challenge to Public Administration in Austria. American Behavioral Scientist, 49(7), 1000-1014. 
Miklos, D., HV, V., Lee, G. (2016). Bracing for seven critical changes as fintech matures. New York, EUA. McKinsey \& Company Financial Services. Retrieved August 03, 2019, from https://www.mckinsey.com/industries/financialservices/our-insights/bracing-for-seven-criticalchanges-as-fintech-matures

PWC (2016). Financial Services Technology 2020 and Beyond: Embracing disruption. Retrieved August 03, 2019, from https://www.pwc.com/gx/en/financial-services/assets/pdf/technology2020-and-beyond.pdf

PWC Brasil (2018). Pesquisa Fintech Deep Dive 2018. Retrieved August 03, 2019, from https://www.pwc.com.br/pt/setores-de-atividade/financeiro/2018/pub-fdd-18.pdf.

Reay, T., Hinings, C.R. (2005). The recomposition of an organizational field: Health care in Alberta. Organization Studies, v.26, n.3, pp.351-384.

Resolução $\mathrm{n}^{\mathrm{o}} 4.656$ de 26 de abril de 2018 (2018). Banco Central do Brasil. Retrieved from https://www.bcb.gov.br/pre/normativos/busca/downloadNormativo.asp?arquivo=/Lists/Normativos/Attachments/505 79/Res_4656_v1_O.pdf.

Resolução $\mathrm{n}^{\circ} 4.657$ de 26 de abril de 2018 (2018). Banco Central do Brasil. Retrieved from https://www.bcb.gov.br/pre/normativos/busca/downloadNormativo.asp?arquivo=/Lists/Normativos/Attachments/505 80/Res_4657_v1_O.pdf.

Thornton, P. H., Jones, C., Kury, K. (2005). Institutional Logics and Institutional Change in Organizations: Transformation in Accounting, Architecture, and Publishing, in Jones, C, Thornton, P. H. (ed.) Transformation in Cultural Industries (Research in the Sociology of Organizations, Volume 23) Emerald Group Publishing Limited, pp.125 - 170

Thornton, P., \& Ocasio, W. (1999). Institutional Logics and the Historical Contingency of Power in Organizations: Executive Succession in the Higher Education Publishing Industry, 1958- 1990. American Journal of Sociology, 105(3), 801-843. 